\title{
Acculturative Stress among International Students at Airlangga University - Indonesia
}

\author{
Shahzad Ali ${ }^{1}$ (D), Nono Hery Yoenanto ${ }^{1, *}$ (D), and Duta Nurdibyanandaru ${ }^{1}$ \\ ${ }^{1}$ Department of Educational and Developmental Psychology, Faculty of Psychology, \\ Airlangga University, 60286, Surabaya, Indonesia \\ * Corresponding Author: nono.hery@psikologi.unair.ac.id
}

\section{ARTICLE INFO}

\section{Publication Info:}

Research Article

How to cite:

Ali, S., Yoenanto, N. H., E Nurdibyanandaru, D. (2020).

Acculturative Stress among

International Students at

Airlangga University - Indonesia.

Society, 8(1), 123-135.

DOI : 10.33019/society.v8i1.150

Copyright (C) 2020. Owned by Author(s), published by Society

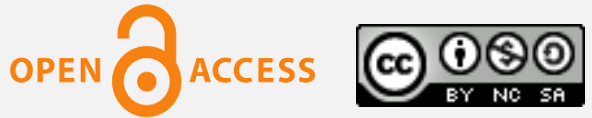

This is an open-access article.

License: Attribution-

NonCommercial-ShareAlike (CC BY-NC-SA)

Received: February 17, 2020;

Accepted: May 9, 2020;

Published: May 16, 2020;

\section{ABSTRACT}

Globalization and the development of modern education systems make foreign students more important in higher education. In Indonesia, in recent years the number of international students has increased. International students, supervisors, and institutions are trying to identify possible ways that can help foreign students adapt to the Indonesian environment, which has its uniqueness. This research aims to investigate the level of acculturative stress experienced by international students of Airlangga University, Indonesia. Specifically, it focused on international students of master programs originating from countries on the African continent. This research was quantitative research. Participants in this research were 40 students. Participants were selected using a purposive sampling technique. The questionnaire was used to collect data and the results were analyzed using SPSS software. Acculturative Stress Scale for International Students (ASSIS) was used to determine the homesickness experienced by the participants. This research found that significant positive acculturative stress among international students $(S D=23.87333)$, (mean=3.00) on homesickness. The result shows that international students experience homesickness because of not having experience living in a different culture and country. The results showed that African students are experiencing high homesickness.

Copyright (C) 2020. Owned by Author(s), published by Society. This is an open-access article under the CC-BY-NC-SA license. https://doi.org/10.33019/society.v8i1.150

Keywords: Acculturative Stress; African International Students; Airlangga University; Homesickness 


\section{Introduction}

The expectations to get international educational exposure, for students, are increasing day by day. Especially in the context of the African continent which has fewer resources and low economic, the students opting to enroll to study at universities around the world are already common practices. In 2016, the movement of students to study at universities around the world has increased to 4 million students. In 2000, only 2 million students enrolled at various universities around the world. This number has doubled in 2016 (UNESCO, 2016). NonEuropean students face bad experiences such as acculturative stress, discrimination, low acceptance from universities in the destination country, and adaptation problems.

Though, the UK, USA, Germany, Australia, and France are the prior destined selection for international students. The figure for enrolment in these prior countries has decreased from fifty-six percent in 2000 to fifty percent in 2013 (UNESCO, 2016). Students look for new destinations such as the Middle East and ASEAN regions because countries in these regions provide scholarships to international students regardless of ethnicity, nationality, and religion, another thing is fewer restrictions on a visa from these countries (Fischer, 2015; Garrett, 2014). Scholarships and such kinds of funding opportunities attract students to get an education in a country with a new culture. However, some students are unable to adapt to cultural differences or cannot communicate in communities in the host country. This leads to some psychological problems experienced by international students such as cultural shock, language barriers, and homesickness.

Acculturative stress is an experience when people adopt a culture that is new to them, adaptation problems lead an individual towards the discouraging in facing the challenges in an adaptation of new culture that become the cause of stress ( $\mathrm{Li}$ et al., 2017). Studies depict that acculturative stress resulted in a decline among the physical, social, and psychological, the stability of people or groups. The difference in stress is largely caused by similarities or discrepancies between home and host country cultures of newcomers (Zhang \& Jung, 2017). This includes personality traits, amount of disclosure, educational and skill capabilities, gender, age, ethnicity, race, color and creed, language, religious psychological and strength, as well as social, political boldness for host culture, especially to newcomers. The extra radical and dissimilar host culture, unlike the newcomer's native cultures, will be supplemented with additional cultural stress. Individuals face several problems when they are going to adopt a new culture that is new for them or different for them because of socially and culturally norms that also the cause of stress for individuals (Imamura \& Zhang, 2014).

Numberless students from different countries and different continents are studying at Airlangga University. Most of them are studying for a Master's degree. The new culture and language barrier play the role in causing some issues regarding cultural shock and different concerns. The current research conducted to highlight the issues of international students specially belongs to the African continent. The previous research conducted at Universiti Kebangsaan Malaysia "Acculturative stress among international postgraduate students at UKM" will support the current research. The international students in Universiti Kebangsaan Malaysia suffered from homesickness and acculturative stress (Desa et al., 2012).

\section{Literature Review}

Sandhu \& Asrabadi (1994) stated that relocating to a new environment from their homeland can result in inner stress. Remembering of friends, family, and loneliness are mutual indicators spoken by overseas students. Staying far from parents and siblings, means they need to live not having the supportive environment that they had in their homeland, which could cause give

Copyright (C) 2020. Owned by Author(s), published by Society. This is an open-access article under the CC-BY-NC-SA license. 
rise to possible pressure of stress. They would face new practices in the concerns of family high expectations and sponsors of the host education system for performance to achieve high educational outcomes.

Although new students need time to familiarize and settle in new environments, the success for these beginners of the new education system is based on the way that institution will improve to tackle the stress psychologically. Hence, while relocating to the new culture and environment of the host country, the purpose of the students is to learn about the people and get acquainted with the social and cultural life of the host nation. Foreign students belong to different cultural countries and come with the unique personality traits that they adopt from their home country culture. The most important factor or element in foreign students is cultural sensitivity. They could be confused according to the cultural variations among their homeland culture and the culture of hosting countries that may affect the objectives, motivation, and feelings. Several studies have been conducted on Chinese students that are studying in France and other European countries showed similar results that Chinese students are experiencing adjustment or social difficulties (Cao et al., 2016).

A research conducted by Bierwiaczonek \& Waldzus (2016) categorized there are 5 backgrounds regarding the adaptation of sociocultural that are discussed in the current study, consisting of 1) space in culture (e.g., a new culture or not knowing the norms of the host culture), 2) communication within the community (e.g., number of contacts in society), 3) prejudice (e.g., discrimination), 4) societal resources (e.g., depends on the support from the friends), and 5) family-based adaptation (e.g., single or married). The students should know how to interact with intercultural relations, food, and social living style differences. The fact is that foreign students who study at Indonesian universities are required to learn the Indonesian language and native culture simultaneously. Although the fundamental principle is to truly provide them cultural diversity of host countries, it can subsidize the current pressure as adjusting the environment that is new for them, can be tough and miserable which can result in acculturative stress. International students also face the challenges of acceptance and values.

They should adopt the new ways of thinking and acting being adjustable personalities in host country culture and environment. It is suggested due to significant cultural differences between home education, environment, and sudden cultural changes from the home country including academic educational system, communication problems due to different languages and cultural diversity. These barriers can emerge finding difficult having friends and a peer group of their home, they will be exposed to stress. Several investigations suggested that the short or long stay of students in guest countries where they went for education showed that the level of acculturative stress is high than in other groups. Thus, international students experience acculturative stress from the group mates rather than direct from the society of the host country. They face stress from the fellows where they are studying or host country, the attitude towards them from the group mates cause of stress (Vezzali et al., 2017).

Foreign students also have limited resources being a student while coming to the host country. There are multiple opportunities available for local students e.g. loan and scholarships but not for international students. Foreign students also have to experience further stressors, like adjustment problems with less connection in the community. For instance, being an international student in an unfamiliar place or country, they have to create their presence and space by adjustment while getting an education there (Wu et al., 2015). As a result of this stress, they will receive surely more difficulties in acculturating and establishing the cultural groups. An investigation in the United States of America is suggested that students who come to study in America belong to diverse academic backgrounds. The comers face the problems or

Copyright ( $(2020$. Owned by Author(s), published by Society. This is an open-access article under the CC-BY-NC-SA license. https://doi.org/10.33019/society.v8i1.150 
difficulties in adapting the new education culture which is unknown for them, like grading score in academics, presentations either oral or poster, several quizzes in each subject, library system, and problem in-class participation for discussions as an active student (Wu et al., 2015). This is largely because of tackling the issues related to hosting culture, which they have to face during academic stress without resources as compare to domestic (Sandhu \& Asrabadi, 1998). The mutual effects of these stresses and the availability of resources to relocate make students highly sensitive to the hurtful effects of acculturative stress. Furthermore, international students face a larger phase of stress related to mental illness because they could not get appropriate psychological guidance to tackle the fear of failure. The number of studies found that acculturative stress is the common cause of depression, anxiety, bipolar disorder, and suicidal risks among international students.

The psychological and physical burden for adjustment is a cause of acculturative stress (Han et al., 2017). The language barrier, ethnic, cultural prejudice, racism, homesickness, fear, hate, and cultural shock are might the major contributors to acculturative stress (Wu et al., 2015). This situation or condition leads them towards psychological problems like depression and anxiety (Sullivan \& Kashubeck-West, 2015). Deprivation in psychological or mental health is normally connected with changes in life while experiencing acculturation, for example not having family support, fear of loss, less role in society, or less social networking (Akhtar \& Kröner-Herwig, 2015).

Various variables are interlinked with the acculturation procedure; one of the most obviously spoken in the literature is the issue of social support, acculturative stress, and homesickness. Social assistance or social support is the main element that is faced by foreign students (Caricati et al., 2017). There are six extents in which the immigrants face the changing practice like personality, language, cognition level, identification, acculturative stress, and attitude (Rodriguez et al., 2015). In the first six months of immigration, students face cultural shock in residence in the host country. Though, an ethnographic study among international students of South of England universities conducted by Brown \& Holloway (2008) found that students initially do not have adjustment problems but they also stated somehow students have feelings of intercultural adjustment because of cultural shock. To go to other countries, it suddenly withdraws the pre-established supportive system and becomes the cause of confusion, anxiety, and lack of confidence. Students who belong from a collectivized culture like Asia, Latin America, and Africa face many problems in the cultural adaptation as compare to the students from Europe who enrolled in the college in the United States of America where independence and individuality existed as culture (Akhtar \& Kröner-Herwig, 2015).

\subsection{Academic Experiences}

In the globalization, everything is becoming an industry. Same as that, the educational institutions become industry too and providing the number of opportunities to the students regardless of ethnicity, race, religion, nationality, and culture to attain education. These opportunities become part of life as an academic experience (Lee \& Negrelli, 2018). An academic experience denotes those experiences which are associated with education and distinct as psychologically or mentally satisfied state that infers student academic expectation. Through such measurement can also evaluate the institution's performance. When international students start studying in the first-year classes, they face various concerns related to participation in the classroom, instructions about the classroom, and discussions in the classroom, facing the expectations or hopes from the lecturers. They also face the stress of academic achievements to be graduates. To encourage students to achieve goals and to make

Copyright ( $(2020$. Owned by Author(s), published by Society. This is an open-access article under the CC-BY-NC-SA license.

https://doi.org/10.33019/society.v8i1.150

126 
sure the interaction between teachers and students (i.e., after class student can approach or meet with a teacher) is recommended (Choi, 2015). In the first month of the student life, abroad orientation program can also help find ways to cope with such concerns. Additionally, helping foreign students increase their language proficiency can lead to a greater level of self-efficacy in academics (Moon et al., 2020). There are some difficulties such as lacking in non-professional staff, an unsuitable academic environment, and less academic staff presence to help in academic performance (Fadel et al., 2018). Often foreign students belong to more traditional cultural countries e.g., Asian. This can experience distance in the culture of the United States of America and face some adjustment problems. Additionally, as perceived bias increases, international students will also be identified with other international students such as ethnic and language problems (Li et al., 2017).

\subsection{Societal Experiences}

International students can show multiple reactions about the culture of the hosting country, some people participate in the social events that are new for them in the host country, while others feel distant. As a variable that influences this attitude, it is a positive approach to combine the culture of the home and host, perceived discrimination, backwardness, great communication skills, and relationships with other students (Lantrip et al., 2015). However, as the students start to get engage with the community, they experience social support from Americans and become a positive sign.

\subsection{Psychological Experiences}

Psychological experience includes a person's cognitive level of thinking, perception, consciousness, emotion, memory, thinking pattern, and process of cognition. Psychological experience is also referring to as a correlation between daily experiences and psychological dealing against issues while facing experiences and such experiences occur gradually. In the first phase of transition international students can feel confusion, lack of confidence, loss of self, being isolated, and helpless. Though dissimilar to other students, foreign students commonly do not have resources like domestic students to overcome stress (Sandhu \& Asrabadi, 1998). The absence of resources, as well as psychological experiences, can lead to severe anxiety or depression. There is more or less evidence that international students' culture depicts the number of types of psychological problems they reacted to. The international students in the United States of America who belong to Asia, Central Africa, and South America, face more acculturative stress rather students belong to Europe (Claudat et al., 2016). Being an international student in any country could be the cause of some extra adjustment issues (Ward \& Geeraert, 2016). Foreign students mostly face (a) estrangement (failure feelings to accomplish the desired results), (b) meaninglessness (sometimes unable to understand what is happening with them), and (c) social estrangement (being alone feelings).

This research aimed to investigate International students from African who are experiencing acculturative stress on different levels among students of different gender and age groups.

\section{Research Methodology}

This research was quantitative research. Participants in this research were 40 students. Participants were selected using a purposive sampling technique. The questionnaire was used to collect data and the results were analyzed using SPSS software. Acculturative Stress Scale for International Students (ASSIS) developed by Sandhu \& Asrabadi (1994) was used to determine 
the homesickness experienced by the participants. Simple descriptive statistics with mean were used to analyze the results due to its universal applicability as commonly adopted statistical techniques by scholars. This research was conducted in July 2019.

\subsection{Instrument}

The Acculturative Stress Scale for International Students (ASSIS) scale is consists of 36-items and adapted to a 5-point Likert scale (originally 5-point scale 1=strongly disagree to 5=strongly agree). ASSIS consists of 7 subscales; Perceived discrimination (eight items), Homesickness (four items), Perceived hate (five items), Fear (four items), Stress due to change/culture shock (three items), Guilt (two items), and Miscellaneous (10 items). The scale score range from 36 to 180, the lowest score is 72, 73. The moderate score of ASSIS is 144 and above 144 to 180 is high scoring (Jean-Paul, 2015).

Table 1. Reliability tests results were conducted on ASSIS and the Cronbach Alpha

\begin{tabular}{|clc|}
\hline S & Item & C Alpha \\
$\mathbf{1}$ & Perceived Discrimination Items & 0.792 \\
\hline $\mathbf{2}$ & Homesickness Items & 0.697 \\
\hline $\mathbf{3}$ & Perceived Hate Items & 0.830 \\
\hline $\mathbf{4}$ & Fear Items & -0.265 \\
\hline $\mathbf{5}$ & Stress Due to Change/Culture Shock Items & 0.711 \\
\hline $\mathbf{6}$ & Guilt & 0.977 \\
\hline $\mathbf{7}$ & Miscellaneous & 0.734 \\
\hline
\end{tabular}

C Alpha of subscale Fear is negative -0.265 either but still used for data collection.

\section{Results and Discussion}

Table 2. The total number of respondents based on the three levels (minimum and maximum) score

\begin{tabular}{|lcccccc|} 
& N & Minimum & Maximum & Sum & Mean & Std. Deviation \\
SA & 40 & 28.00 & 94.00 & 253.00 & 63.2500 & 23.87333 \\
\hline Valid N & 40 & & & & & \\
(Listwise) & & & & & &
\end{tabular}

The test results show that the participant has the lowest score is 28.00 and the highest score is 94.00 , the mean score is 63.25 and the standard deviation is 23.87333 .

Table 3. The test results on International Students used ASSIS

\begin{tabular}{|lc|}
\hline Sub Scale & Mean \\
\hline Perceived Discrimination & 1.75 \\
\hline Homesickness & 3.00 \\
\hline Perceived Hate & 1.6 \\
\hline Fear & 1.56 \\
\hline Stress Dues to Change/Culture Shock & 1.91 \\
\hline Guilt & 2.125 \\
\hline
\end{tabular}

Copyright ( $(2020$. Owned by Author(s), published by Society. This is an open-access article under the CC-BY-NC-SA license. https://doi.org/10.33019/society.v8i1.150 
Table 3 shows the highest subscale of ASSIS in this research is the homesickness that has mean $=3.00$, and guilt feelings on the second that has mean $=2.125$. It shows that the students have guilt feelings in concerns for choosing the destination. The stress due to change/culture shock that has mean $=1.91$ which is showing that after the guilt feelings the most stressful for African students is a cultural shock. In the fourth place is perceived discrimination that has mean $=1.75$. It shows that they are facing racial discrimination in the community. The lowest one is the perceived hate subscale that has mean $=1.6$.

\section{Table 4. Sum of score based on Items}

\begin{tabular}{|c|c|c|}
\hline Item & & Sum of Score \\
\hline & I miss the country and people of my national origin. & 13.00 \\
\hline 35) & I feel sad about leaving my relatives behind. & 13.00 \\
\hline 8) & I feel intimidated to participate in social activities. & 6.00 \\
\hline 12) & I feel angry that my people are considered inferior here. & 6.00 \\
\hline 13) & $\begin{array}{l}\text { I feel overwhelmed that multiple pressures are placed upon me after I } \\
\text { migrate to this community. }\end{array}$ & 6.00 \\
\hline 23) & I feel that my people are discriminated against. & 6.00 \\
\hline 24) & $\begin{array}{l}\text { People from some other ethnic groups show hatred toward me through their } \\
\text { actions. }\end{array}$ & 6.00 \\
\hline 19) & I have to frequently relocate for fear of others. & 1.00 \\
\hline 36) & $\begin{array}{l}\text { I worry about my future for not being able to decide whether to stay here or } \\
\text { to go back. }\end{array}$ & 1.00 \\
\hline
\end{tabular}

Item numbers 21 and 35 have the highest score from the participant. Item numbers 8, 12, 13, 23, 24 are the items that have a moderate score, and the item numbers 19 and 36 are the items that have the lowest score.

\subsection{Discussion}

The results indicate that the students from Africa at Airlangga University are experiencing acculturative stress (mean $=1.88$, see Table 3 ). The results show culture shock and changing environment is the causes of stress. This can also be seen on perceived hate and homesickness (see Table 3) as the acculturative stress factors with the highest mean as reported by African students at Airlangga University. The results emphasize that African students at Airlangga University are adjusting in a new community that is somewhat conventional and traditional, which can be hard for them to settled or understand. This research proves that the host community which is multi-cultural with various ethnic groups is difficult to adjust for international students as at Airlangga University. This is another reason for international students fail to manage to make themselves fully opt-in Indonesian because of less time.

A majority of the Indonesian community is unable to communicate in the English language. It is also a challenge for international students to learn Indonesian or local language to survive in the community. As per the results of Table 4 indicating students are facing homesickness 
with a sum of score item number of $21=13.00$ and sum of score item number of $35=13.00$. Culture shock arises when someone cannot live a social lifestyle like in the past he/she had and forced to get the new social lifestyle (Zhang \& Jung, 2017). As per the findings of this research, homesickness is on the highest with mean $=3.00$. When someone is going to adapt new culture, that individual will face psychological problems i.e. loneliness, anxiety, depression, distress, or the feeling of failure to adopt the cultural changes comparing with the homeland and host country. Confusion in terms of functions in a society that is new can result in hate and anger towards the culture; this is called "culture shock" (D'Anna-Hernandez et al., 2015). Furthermore, as per the results of this research, fear is not a factor of acculturative stress for international students at Airlangga University.

Being a foreign student should make new social groups for socialization that will support the social adaptation which will be also helpful to overcome stress (Forbush \& Foucault-Welles, 2016). By doing this, they will be able to trust themselves and will know how to control the stress on their own. Hence, international students at Airlangga University must try to overcome stress, academically settle, and trust themselves to be successful in academic achievement. To overcome the stress of culture shock because of sudden change, international students should act motivated and present themselves as a strong personality to tackle stress and challenging problems. This is because they have distance from their family and living without support. The findings also suggest that when students live far away from their homes the homesickness will rise. This is because they used to live in an environment where friends and family are always there to support (Sullivan \& Kashubeck-West, 2015). This can also be a reason of homesickness for individuals who want to go back to the known culture and environment. International students who live far away from their families face such stress because of feelings of loneliness, missing food, culture, and lifestyle. Such type of situation can make them even worst because they are not willing to open up and share their feelings and emotions. Another reason to be isolated from society and feeling homesickness is differences in culture and language barriers.

Foreign students very shy and self-controlled to disclose their feelings, emotions, and societal concerns among peer groups (Sam et al., 2015). This is because they make their relationship with only classmates when they are in the class. Language is the main platform of communication for social networking where an individual is living. But some studies investigate that the barrier of language is also the indicator of homesickness with the second highest mean (mean=3.00, see Table 3). International students also experience hate when they face an uncomfortable environment. It denotes that the international students perceive the negative attitude of people around them. In the acculturative stress context, these are the feelings of hate which are the individuals' negative feelings for the culture surrounding them (Poyrazli et al., 2010).

It is very difficult to join a new culture that is challenging also can result in the adjusting process for international students. Usually, adequate results in the context of perceived hate, cultural shock, language barrier and homesickness, present stressful behavior in international students; i.e. misunderstanding, unhappiness, unease, confusion, loneliness feelings, and the probable problem of distinctiveness affecting acculturative stress (Rhein, 2017). The findings of this study resemble the study done by Zhai (2004) found that perceived hate in educational institutions also a cause of increasing stress and adjusting in the society for international students (Bertram et al., 2014). 


\subsection{Recommendations}

The current research proposes that Airlangga University should make a mechanism for international students that can be fruitful for them and they can feel like part of a new community. By adopting this, international students will face less stress and can achieve academic goals smoothly. In the beginning, the International Office of Airlangga University should facilitate students with a friendly environment, because all international students face problems like accommodation, cultural barriers, language barriers, and homesickness. Airlangga University should highlight how international students are important for their campus. Every faculty in the university with international students should arrange some events that can play the facilitative role to reduce the acculturative stress and perceived hate in international students. This can be productive to improve their academic performance and success as well.

The current findings also suggest that the administration of Airlangga University should organize a system of counseling in such a way that it helps in overcoming the acculturative stress and other psychological problems. Such type of steps and activities would help lessen the stress, adjustment problems, environmental factors, and also can reduce homesickness and cultural shock that might become the reason of bad performance in academics and the community as well. Airlangga University also has a responsibility to arrange some activities and different cultural events for international students that can help to overcome the gap between the community and international students. It will help them to learn culture and language. The recommendations from this study can help university administration, services of counseling, and the relationship between the academic and non-academic staff of the university.

The supporting behavior of academicians can be helpful in the adjustment process for foreign students. For this purpose, Airlangga University should also arrange counseling sessions from the professional psychologist. Getting enrolled is a lead to adaptation in the culture as well but it takes time for international students. The other thing that Airlangga University also needs to do is to caretake of the financial issues of students who are on scholarships at Airlangga University. The International Office at the Universities is the option to know the information about anything either regarding culture and academics for foreign students. The current research emphasizes that the International Office at Airlangga University should take care of international students in terms of assisting them, asking them about their stay and facilities in dormitories.

\subsection{Limitations and Future Research}

This investigation based on one ethnic group of African students who were currently enrolled at Airlangga University. For future research, we would like to recommend the researchers to expand the research by including other universities and ethnic groups.

\section{Conclusion}

The investigation of current research shows that international students face adjustment and adaptation problems, i.e. homesickness and cultural shock in the hosting country. This research also suggests that international students at Airlangga University have a moderate level of acculturative stress. The international students should mold themselves towards the adjustment and adaptation in the new environment and culture of hosting the country on an immediate basis to face the least stress and other psychological problems that arise for a strange or new individual. The research concluded to the authorities, policymakers, and decision-makers to 
establish a plan at the beginning of the academic sessions that should be based on extraordinary support and assistance and organize special events about intercultural relations which will be helpful to overcome acculturative stress. If international students easily communicate in the community, they will be able to adjust and can improve self-esteem. It can conclude that the significant relationship between homesickness and acculturative stress on international students at Airlangga University causing individual psychological sickness.

\section{Acknowledgment}

The authors wish to thank all participants who have provided help and information during this research conducted.

\section{Declaration of Conflicting Interests}

The authors declared no potential conflicts of interest with respect to the research, authorship, and/or publication of this article.

\section{References}

Akhtar, M., \& Kröner-Herwig, B. (2015). Acculturative stress among international students in context of socio-demographic variables and coping styles. Current Psychology, 34(4), 803815. https:/ / doi.org/10.1007/s12144-015-9303-4

Bertram, D. M., Poulakis, M., Elsasser, B. S., \& Kumar, E. (2014). Social support and acculturation in Chinese international students. Journal of Multicultural Counseling and Development, 42(2), 107-124. https:/ / doi.org/10.1002/j.2161-1912.2014.00048.x

Bierwiaczonek, K., \& Waldzus, S. (2016). Socio-cultural factors as antecedents of cross-cultural adaptation in expatriates, international students, and migrants: A review. Journal of CrossCultural Psychology, 47((6)), 767-817. https://doi.org/10.1177/0022022116644526

Brown, L., \& Holloway, I. (2008). The initial stage of the international sojourn: excitement or culture shock?. British Journal of Guidance $\mathcal{E}$ Counselling, 36(1), 33-49. https:/ / doi.org/10.1080/03069880701715689

Cao, C., Zhu, D. C., \& Meng, Q. (2016). An exploratory study of inter-relationships of acculturative stressors among Chinese students from six European union (EU) countries. International Journal of Intercultural Relations, 55, 8-19. https:/ / doi.org/10.1016/j.ijintrel.2016.08.003

Caricati, L., Mancini, T., \& Marletta, G. (2017). The role of ingroup threat and conservative ideologies on prejudice against immigrants in two samples of Italian adults. The Journal of Social Psychology, 15(1), 86-97. https:// doi.org/10.1080/00224545.2016.1176552

Choi, J. Y. (2015). Reasons for silence: A case study of two Korean students at a US graduate school. TESOL Journal, 6(3), 579-596. https://doi.org/10.1002/tesj.209

Claudat, K., White, E. K., \& Warren, C. S. (2016). Acculturative stress, self-esteem, and eating pathology in Latina and Asian American female college students. Journal of Clinical Psychology, 72(1), 88-100. https://doi.org/10.1002/jclp.22234

D’Anna-Hernandez, K. L., Aleman, B., \& Flores, A. M. (2015). Acculturative stress negatively impacts maternal depressive symptoms in Mexican-American women during pregnancy. Journal of Affective Disorders, 176, 35-42. https:/ / doi.org/10.1016/j.jad.2015.01.036

Desa, A., Yusooff, F., \& Kadir, N. B. A. (2012). Acculturative Stress Among International Postgraduate Students at UKM. Procedia - Social and Behavioral Sciences, 59, 364-369. https:// doi.org/10.1016/j.sbspro.2012.09.287

Copyright (C) 2020. Owned by Author(s), published by Society. This is an open-access article under the CC-BY-NC-SA license. 
Fadel, C. B., Souza, J. A. D., Bordin, D., Garbin, C. A. S., Garbin, A. J. Í., \& Saliba, N. A. (2018). Satisfaction with the academic experience among graduate students of a brazilian public university. RGO-Revista Gaúcha de Odontologia, 66(1), 50-59. https://doi.org/10.1590/1981863720180001000073261

Fischer, K. (2015). Why growth in international enrollments could soon be slowing. The Chronicle of Higher Education. Retrieved from http://chronicle.com/article/Why-Growthin-International/234181

Forbush, E., \& Foucault-Welles, B. (2016). Social media use and adaptation among Chinese students beginning to study in the United States. International Journal of Intercultural Relations, 50(1), 12. https:/ / doi.org/10.1016/j.ijintrel.2015.10.007

Garrett, R. (2014). Explaining international student satisfaction: Initial analysis of data from the International Student Barometer. Boston, MA: i-Graduate.

Han, S., Pistole, M. C., \& Caldwell, J. M. (2017). Acculturative stress, parental and professor attachment, and college adjustment in Asian international students. Journal of Multicultural Counseling and Development, 45(2), 111-126. https:// doi.org/10.1002/jmcd.12068

Imamura, M., \& Zhang, Y. B. (2014). Functions of the common ingroup identity model and acculturation strategies in intercultural communication: American host nationals' communication with Chinese international students. International Journal of Intercultural Relations, 43(PB), 227-238. https:// doi.org/10.1016/j.ijintrel.2014.08.018

Jean-Paul, M. (2015). Acculturative stress and self-reported English fluency in international students in Ireland: a quantitative study. Bachelors Final Year Project, Dublin Business School. http://hdl.handle.net/10788/2497

Lantrip, C., Mazzetti, F., Grasso, J., Gill, S., Miller, J., Haner, M., \& Awad, G. (2015). Ethnic identity and acculturative stress as mediators of depression in students of Asian descent. Journal of College Counseling, 18(2), 144-159. https:/ / doi.org/10.1002/jocc.12011

Lee, J., \& Negrelli, K. (2018). Cultural identification, acculturation, and academic experience abroad: A case of a joint faculty-led short-term study abroad program. Journal of International Students, 8(2), 1152-1072. https://doi.org/10.32674/jis.v8i2.138

Li, Z., Heath, M. A., Jackson, A. P., Allen, G. E. K., Fischer, L., \& Chan, P. (2017). Acculturation experiences of Chinese international students who attend American universities. Professional Psychology: Research and Practice, 48(1), 11-21. https://doi.org/10.1037/pro0000117

Moon, C. Y., Zhang, S., Larke, P., \& James, M. (2020). We are not all the same: A qualitative analysis of the nuanced differences between Chinese and South Korean international graduate students' experiences in the United States. Journal of International Students, 10(1), 28-49. https:// doi.org/10.32674/jis.v10i1.770

Poyrazli, S., Thukral, R. K., \& Duru, E. (2010). International students' race-ethnicity, personality and acculturative stress. Journal of Psychology and Counseling, 2(8), 25-32.

Rhein, D. (2017). International Higher Education in Thailand: Challenges within a Changing Context. Journal of Alternative Perspectives in the Social Sciences, 8(3), 281-298.

Rodriguez, N., Flores, T., Flores, R. T., Myers, H. F., \& Vriesema, C. C. (2015). Validation of the Multidimensional Acculturative Stress Inventory on adolescents of Mexican origin. Sychological Assessment, 27(4), 14-38. https://doi.org/10.1037/pas0000125

Sam, D. L., Tetteh, D. K., \& Amponsah, B. (2015). Satisfaction with life and psychological symptoms among international students in Ghana and their correlates. International Journal of Intercultural Relations, 49, 156-167. https:/ / doi.org/10.1016/j.ijintrel.2015.09.001

Copyright (C 2020. Owned by Author(s), published by Society. This is an open-access article under the CC-BY-NC-SA license. https://doi.org/10.33019/society.v8i1.150 
Sandhu, D. S., \& Asrabadi, B. R. (1994). Development of an Acculturative Stress Scale for International Students: preliminary findings. Psychological Reports. https:// doi.org/10.2466/pr0.1994.75.1.435

Sandhu, D. S., \& Asrabadi, B. R. (1998). An acculturative stress scale for international students: A practical approach to stress management. Evaluating stress: A book of resources, 2, 1-33.

Sullivan, C., \& Kashubeck-West, S. (2015). The Interplay of International Students' Acculturative Stress, Social Support, and Acculturation Modes. Journal of International Students, 5(1), 1-11. https://www.ojed.org/index.php/jis/article/view/438

UNESCO. (2016). Global flow of tertiary-level students. Paris: UNESCO Institute for Statistics.

Vezzali, L., Hewstone, M., Capozza, D., Trifiletti, E., \& Bernardo, G. A. D. (2017). Improving intergroup relations with extended contact among young children: Mediation by intergroup empathy and moderation by direct intergroup contact. Journal of Communi, 27(1), 35-49. https:// doi.org/10.1002/casp.2292

Ward, C., \& Geeraert, N. (2016). Advancing acculturation theory and research: The acculturation process in its ecological context. Current Opinion in Psychology, 8, 98-104. https:// doi.org/10.1016/j.copsyc.2015.09.021

Wu, H. P., Garza, E., \& Guzman, N. (2015). International student's challenge and adjustment to college. Education Research International, 1-9. https://doi.org/10.1155/2015/202753

Zhai, L. (2004). Studying International Students: Adjustment Issues and Social Support. Journal of International Agricultural and Extension Education, 11(1), 98-104. https:// doi.org/10.5191/jiaee.2004.11111

Zhang, Y., \& Jung, E. (2017). Multi-Dimensionality of Acculturative Stress among Chinese International Students: What Lies behind Their Struggles? International Research and Review, 7(1), 23-43. Retrieved from http:/ / ezproxy.lib.uconn.edu/login?url=https:// search.ebscohost.com/login.aspx?direct $=$ true $\& \mathrm{db}=$ eric $\& A N=E J 1170666 \&$ site $=$ ehost-live

\section{About the Authors}

1. Shahzad Ali, a graduate student at the Department of Educational and Developmental Psychology, Faculty of Psychology, Airlangga University, Indonesia.

E-Mail: shahzad.ali-2018@psikologi.unair.ac.id

2. Nono Heri Yoenanto, obtained his Doctoral degree in Educational Psychology from Airlangga University, Indonesia, in 2018. The author is an Associate Professor at the Department of Educational and Developmental Psychology, Faculty of Psychology, Airlangga University, Indonesia. His expertise includes Educational Psychology and Psychology of Gifted Children's Education. His research interest includes giftedness, and facilitation for classroom learning.

E-Mail: nono.hery@psikologi.unair.ac.id

3. Duta Nurdibyanandaru, obtained his Doctoral degree in Developmental Psychology from Airlangga University, Indonesia, in 2017. The author is an Associate Professor at the Department of Educational and Developmental Psychology, Faculty of Psychology, Airlangga University, Indonesia. His expertise includes Developmental Psychology, Legal

Copyright $\odot$ 2020. Owned by Author(s), published by Society. This is an open-access article under the CC-BY-NC-SA license. https://doi.org/10.33019/society.v8i1.150 
Psychology, and Pre-marital Counseling. His research interest includes problematic development and developmental problems, and parenting and child resilience development.

E-Mail: duta.nurdibyanandaru@psikologi.unair.ac.id

Copyright (C) 2020. Owned by Author(s), published by Society. This is an open-access article under the CC-BY-NC-SA license. https://doi.org/10.33019/society.v8i1.150 